\title{
EVALUATION EFFICIENCY OF SULPHUR FERTILIZER IN CALCAREOUS SOIL AMENDED BY COMPOST
}

\author{
E. A. Abou Hussien, W. M. Nada and M. Kh. Elgezery \\ Soil Sci. Dept., Fac.of Agric. Menoufia Univ. Shebin El-Kom, Egypt
}

Received: Jan. 2, 2017

Accepted: Jan. 8,2017

\begin{abstract}
A pots experiment was carried out at greenhouse of Soil Sci., Dept., Fac., of Agric., Menoufia Univ., Egypt to study the effect of individual and combined applications of compost and $S$ as soil amendments on calcareous sandy soil properties and its content of available macro and micronutrients barley plants (Hordeum Vulgare L.) growth and its content of macro and micronutrient and agronomical efficiency (AE) of the tested soil amendments. Compost was added at rates of 0,1 and $2 \%$, where $S$ was added as elemental $S$ at rates of 0 , 200,300 and $400 \mathrm{mg} / \mathrm{kg}$. The dry matter yield of barley plants harvested after 70 days of planting and its content of macro and micronutrients were determined. Also, chemical properties of the tested soil and its content of available macro and micronutrients after planting harvesting were determined.

Increasing application rates of compost and $S$ individually and together resulted in a decrease

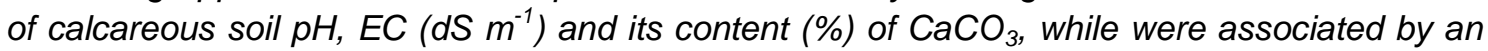
increase soil OM (\%), CEC (meq/100 g) and its content (mg/kg) of available $\mathrm{N}, \mathrm{P}, \mathrm{K}, \mathrm{Ca}, \mathrm{Mg}, \mathrm{S}$, $\mathrm{Fe}, \mathrm{Zn}, \mathrm{Mn}$ and $\mathrm{Cu}$. The high relative changes "RC" (\%) of the studied soil properties were associated the combined treatments of compost and $S$ especially at high application rates. Dry matter yield of barley plants and its content of $\mathrm{N}, \mathrm{P}, \mathrm{K}, \mathrm{Ca}, \mathrm{Mg}, \mathrm{S}, \mathrm{Fe}, \mathrm{Zn}, \mathrm{Mn}$ and $\mathrm{Cu}$ were increase with the increases of added compost and $S$ individually and together. Agronomical efficiency $(A E)$ of both compost and $S$ under calcareous sandy soil conditions were increased in their combined application treatments. So, these results concluded that, to improve the properties of calcareous sandy soil and increased its fertility and productivity must be treated by compost and S together.
\end{abstract}

Key words: Calcareous sandy soil, Compost, Sulphur, Barley plant, Soil amendment, Nutrients uptake and Agronomical efficiency.

\section{INTRODUCTION}

In Egypt desert area represents about $96 \%$ of Egypt total area, where most of desert areas are scattered in the eastern and western parts at the periphery of the Nile Valley and Delta. The reclamation of desert lands to become agriculturally productive is a first priority of the government policy. Calcareous soil is wide occurrence in these regions. Most of newly reclaimed calcareous soil is mainly found in western part of the Nile Delta. The calcareous soils are those with high content of $\mathrm{CaCO}_{3}$, especially the active fraction with high specific surface area which causes some physical problem of these soil and water use for crop production. A soil is considered "calcareous" from the chemical point of view when it is in equilibrium with excess of $\mathrm{CaCO}_{3}$ at the partial pressure of the atmospheric $\mathrm{CO}_{2}$. In the context of agricultural problem soil, calcareous soils are in which a high amount of calcium carbonate dominates the problem related to agricultural soil use. The formation of crusts is a problem in the carbonate - rich soils newly put under cultivation. Crusting which takes place at the soil surface hinders seeding rate of emergence and percentage. The adverse effect of crust depends on their strength and thickness. (Imas, 2000).

Composting is useful in avoiding greenhouse gas emissions, as it is an aerobic process (Nada, 2011). Composting 
has been presented as an environmentally friendly alternative to manage and recycle organic wastes with the aim to produce products used as amendments in agriculture. However, the generation of polluting or odorous gases has become a serious negative environmental impact of the composting process. (Barrington et al., 2002).

Sulphur deficiency in soils is widespread around the world (Mathot and ThélierHuché, 2009) because sulphur is difficult for plants to absorb and results in sterilization and bacteriostatic. Therefore, the addition of sulphur alone may inhibit microbial activity and result in volatilization of H2S (Nasser et al., 2004). Sulphur mineralization is tied closely to $\mathrm{C}$ and $\mathrm{N}$ levels in the soil. Sulphur will become or remain immobilized if either the $\mathrm{C}: \mathrm{S}$ or $\mathrm{N}: \mathrm{S}$ ratios are too large and conditions conducive to $S$ mineralization often lead to $\mathrm{N}$ mineralization. The $\mathrm{N}: \mathrm{S}$ ratio in many soils is in the range of 8-12:1. Carbon: sulphur ratios tend to be more variable (with respect to the $C$ levels) they have been reported in the range from about 57-141:1 (Edwards, 1998). Stotzky and Norman (1961) proposed that C:S ratios less than 900:1 are adequate for maximum microbial activity. This means that sufficient $S$ is present to meet microbial needs and formation of organic $S$ may not be necessary. However, smaller optimal ratios have been suggested by Barrow (1961). Indeed, C:S ratios in the literature are almost always within the 900:1 range; so the range may be too broad and/or other factors beside the $\mathrm{C}: \mathrm{S}$ ratio must be considered when interpreting microbial activity.

Barley (Hordeum Vulgare L.) is one of the most dependable cereal crops in harsh environment it is grown in semiarid areas as well as in cold, short season areas. Local varieties and landraces of barley occupy nearly $80 \%$ of the cultivated areas in west Asia and North Africa and these should be collected before they are losing (Qadir et al., 2008).
This study was carried out to evaluate the effect of different additives of compost and sulphur individually and together on the chemical properties of calcareous sandy soil and its content of available macro and micronutrients. The effect of the studied treatments of plant growth and nutrients uptake was one of the aims of this study. Also, agronomical efficiency of both compost and sulphur was determined.

\section{MATERIALS AND METHODS}

This study was carried out as pot experiment at greenhouse experiment, Soil Sci., Dept., Faculty of Agric., Menoufia Univ., Shebin El-Kom, Egypt to study the effect of different compost and $S$ additives on calcareous sandy soil properties and plant growth. Also, agronomical efficiency of both compost and $\mathrm{S}$ was determined

\section{Soil sampling}

Surface soil samples $(0-20 \mathrm{~cm})$ represented newly reclaimed calcareous soils of Egypt were collected from Village 6, Abu El-Matamir, EL-Behaira Governorate, Egypt. The collected soil samples air-dried, ground, good mixed and sieved through a 2 $\mathrm{mm}$ sieve. Sieved fine soil $(<2 \mathrm{~mm})$ was analyzed for its physical and chemical properties and its content of available macro- and micronutrients according to the methods described by Klute and Dirksen (1986) and Cottenie et al. (1982). The obtained data are recorded in Table (1). Other part of this fine soil was used in the greenhouse experiments as mentioned in the following sections.

\section{Soil amendments}

Two soil amendments.ie. compost and $S$ were used in this study. The used compost was produced from the mixture of maize stalks and farmyard manure at mixed rate of 65:35 by weight for 60 days. Sample of produced compost was taken, air dried, ground and analyzed for its chemical composition according to the methods described by Page et al. (1982). The 
Evaluation efficiency of sulphur fertilizer in calcareous soil amended

obtained data are recorded in Table (2). The used elemental sulphur taken from El Help company, Egypt. The purity of this elemental sulphur was $99 \%$ with $\mathrm{pH}$ value of 6.4 (in suspension of $1: 5)$.

Table (1): Some physical and chemical properties and available nutrients content of the used calcareous soil.

\begin{tabular}{|c|c|c|c|}
\hline \multicolumn{3}{|c|}{ Property and unit } & Values \\
\hline \multirow{3}{*}{\multicolumn{2}{|c|}{ Particle size distribution (\%) }} & Sand & 78.50 \\
\hline & & Silt & 10.30 \\
\hline & & Clay & 11.20 \\
\hline \multicolumn{3}{|c|}{ Textural grade } & Sandy \\
\hline \multicolumn{3}{|c|}{ pH 1:2.5 (soil: water Susp.) } & 8.40 \\
\hline \multicolumn{3}{|c|}{ EC 1:5 (soil: water extract) $\mathrm{dSm}^{-1}$} & 1.42 \\
\hline \multicolumn{3}{|c|}{ Organic matter (\%) } & 0.55 \\
\hline \multicolumn{3}{|l|}{$\mathrm{CaCO}_{3}(\%)$} & 13.95 \\
\hline \multicolumn{3}{|c|}{ CEC meq/100g } & 10.20 \\
\hline \multirow{8}{*}{$\begin{array}{l}\text { Soluble ions } \\
\qquad(\mathrm{meq} / \mathrm{l})\end{array}$} & \multirow{4}{*}{ Soluble cations } & $\mathrm{Ca}^{++}$ & 3.32 \\
\hline & & $\mathrm{Mg}^{++}$ & 1.40 \\
\hline & & $\mathrm{K}^{+}$ & 0.12 \\
\hline & & $\mathrm{Na}^{+}$ & 9.10 \\
\hline & \multirow{4}{*}{ Soluble anions } & $\mathrm{CO}_{3}^{--}$ & 0.00 \\
\hline & & $\mathrm{HCO}_{3}^{-}$ & 3.15 \\
\hline & & $\mathrm{Cl}^{-}$ & 6.90 \\
\hline & & $\mathrm{SO}_{4}^{--}$ & 3.89 \\
\hline \multirow{6}{*}{\multicolumn{2}{|c|}{$\begin{array}{l}\text { Available macronutrients } \\
\qquad(\mathrm{mg} / \mathrm{kg})\end{array}$}} & $\mathrm{N}$ & 45.25 \\
\hline & & $P$ & 4.35 \\
\hline & & K & 925.00 \\
\hline & & $S$ & 7.62 \\
\hline & & $\mathrm{Ca}$ & 20.28 \\
\hline & & $\mathrm{Mg}$ & 10.42 \\
\hline \multirow{4}{*}{\multicolumn{2}{|c|}{$\begin{array}{l}\text { Available micronutrients } \\
\qquad(\mathrm{mg} / \mathrm{kg})\end{array}$}} & $\mathrm{Fe}$ & 4.90 \\
\hline & & $\mathrm{Zn}$ & 1.89 \\
\hline & & $\mathrm{Mn}$ & 6.25 \\
\hline & & $\mathrm{Cu}$ & 0.78 \\
\hline
\end{tabular}


Abou Hussien, et al.,

Table (2): Chemical composition of the used compost.

\begin{tabular}{|c|c|c|}
\hline \multicolumn{2}{|c|}{ Property and unit } & Values \\
\hline \multicolumn{2}{|l|}{ pH 1:2.5 (compost: water) Susp. } & 6.88 \\
\hline \multicolumn{2}{|c|}{ EC 1:5 (compost: water extract) dSm ${ }^{-1}$} & 2.24 \\
\hline \multicolumn{2}{|l|}{ Organic carbon (\%) } & 24.74 \\
\hline \multicolumn{2}{|l|}{ Organic matter (\%) } & 42.65 \\
\hline \multicolumn{2}{|l|}{ Total nitrogen (\%) } & 1.60 \\
\hline \multicolumn{2}{|l|}{$\mathrm{C} / \mathrm{N}$ ratio } & 15.46 \\
\hline \multirow{6}{*}{$\begin{array}{l}\text { Available macronutrients } \\
\qquad(\mathrm{mg} / \mathrm{kg})\end{array}$} & $\mathrm{N}$ & 888 \\
\hline & $P$ & 711 \\
\hline & $\mathrm{K}$ & 2016 \\
\hline & $S$ & 296 \\
\hline & $\mathrm{Ca}$ & 694 \\
\hline & $\mathrm{Mg}$ & 5913 \\
\hline \multirow{4}{*}{$\begin{array}{l}\text { Available micronutrients } \\
\qquad(\mathrm{mg} / \mathrm{kg})\end{array}$} & $\mathrm{Fe}$ & 403 \\
\hline & $\mathrm{Zn}$ & 61 \\
\hline & $\mathrm{Mn}$ & 518 \\
\hline & $\mathrm{Cu}$ & 17 \\
\hline
\end{tabular}

\section{Greenhouse experiments}

In this experiment, 36 plastic pots with 20 $\mathrm{cm}$ diameter and $25 \mathrm{~cm}$ depth were used. Each pot was filled with $5 \mathrm{~kg}$ of fine calcareous soil. The pots were divided into three main groups (12 pots/ main group) representing treatments of compost 0 (C0), 1 (C1) and 2 (C2) \% which equal 0,10 and 20 tons compost /fed, respectively. The pots of each main groups were divided into four sub groups ( 3 pots / sub group) representing sulphur additives treatments 0 (S0), 200 (S1), 300 (S2) and 400 (S3) kg/fed (0, 200, 300 and $400 \mathrm{mg} \mathrm{S} / \mathrm{kg}$ ). All treatments of compost and sulphur were carried out separately before planting. Also before planting super phosphate $\left(15.5 \% \mathrm{P}_{2} \mathrm{O}_{5}\right)$ was applied at rate of $200 \mathrm{~kg} / \mathrm{fed}(200 \mathrm{mg} / \mathrm{kg})$. The studied were arranged in two way randomize blocks in three replicates.
Each pot was sown by 10 grains of barley plant (Hordeum vulgar L.) Variety Giza 123 at $2 \mathrm{~cm}$ depth in 20 November 2014. The pots were irrigated with tap water at $60 \%$ of WHC for each treatment. After complete germination, the plants in each pot were thinned at 5 plants. Irrigation water was added every 5 days to keep the moisture content at $60 \%$ WHC. After 20 days of planting each pots were fertilized by ammonium nitrate $(33.5 \% \mathrm{~N})$ at rate of 100 $\mathrm{kg} / \mathrm{fed}(100 \mathrm{mg} / \mathrm{kg})$. At the same time, each pot was received potassium chloride $(48 \%$ $\left.\mathrm{K}_{2} \mathrm{O}\right)$ at rate of $100 \mathrm{~kg} / \mathrm{fed}(100 \mathrm{mg} / \mathrm{kg})$. Another and equal dose of ammonium nitrate and potassium chloride was added after 42 days of planting. All $\mathrm{N}$ and $\mathrm{K}$ applications were carried out with irrigation water. At the end of the experiment (70 days from sowing), the plants of each pot 
were harvested. The harvested plants were washed by tap water to remove any soil particles. Then the harvested plants were separated to roots and shoots. After that the plants (roots and shoots) air-dried. Then divided into two parts the first was dried at $10{ }^{\circ} \mathrm{C}$ to determine the dry weight and the second parts were dried at $70{ }^{\circ} \mathrm{C}$ to determine some of mineral composition content, after that ground and kept for chemical analysis according by Page et al. 1982. The data of obtained dry matter yield for both roots and shoots of barley was statistically analyzed according to Snedecor and Cochran (1980). In addition, relative changes "RC" (\%) of the data of obtained dry matter yield for both roots and shoots were calculated using (Eq. 1)

$$
\boldsymbol{R C}(\%)=\frac{\boldsymbol{D} \boldsymbol{T}-\boldsymbol{D C}}{\boldsymbol{D C}} \times 100 \quad \text { (Eq.1) }
$$

Where the $D T$ and $D C$ represent dry weights of treated and untreated plants, respectively.

Also the agronomic efficiency " $A E$ " ( $\mathrm{g}$ plant/ $g$ soil amendment) of $S$ or compost additives of both shoots and roots of the plants were calculated using (Eq. 2).

$$
\boldsymbol{A E}=\frac{\boldsymbol{D T}-\boldsymbol{D C}}{\boldsymbol{P}} \quad \text { (Eq. 2) }
$$

Where the $D T$ and $D C$ represent the data of treated and untreated plants, respectively and $P$ represent the application rate $S$ (g/pot) or compost $(\mathrm{g} / \mathrm{pot})$. Soil sample of each pot was taken air-dried, ground, good mixed, sieved through a $2 \mathrm{~mm}$ sieve and kept for some chemical determinations and its content of available macro and micronutrients, according to Cottenie et al. (1982).

\section{Plants Analysis}

Sample of $0.5 \mathrm{gm}$ of oven dried plant material was digested with a mixture of $10 \mathrm{ml}$ concentrated sulphuric acid and 1 to 5 drops perchloric acid on the sandy hot plate at $250^{\circ} \mathrm{C}$ until the flask content become colorless according to Chapman and Partt (1961). Then, the digest was diluted with distilled water to a volume of $100 \mathrm{ml}$. Aliquots from this digest was analyzed for the content of macro and micronutrients, according to Cottenie et al. (1982).

\section{RESULTS AND DISCUSSION Soil properties}

The presented data in Table (3) show that, calcareous soil $\mathrm{pH}, \mathrm{EC}\left(\mathrm{dS} \mathrm{m}^{-1}\right.$ ) and $\mathrm{CaCO}_{3}$ (\%) were decreased with the increase rates of added $S$ and compost individually and together. Individual applications of $\mathrm{S}$ were associated by more decrease of soil $\mathrm{pH}$ and EC compared with that associated the individual applications of compost. On the other hand, the found decrease of soil content (\%) of $\mathrm{CaCO}_{3}$ associated the individual application of compost was higher than that resulted from the individual $S$ applications. More decreases of calcareous soil $\mathrm{pH}, \mathrm{EC}$ and $\mathrm{CaCO}_{3}$ were found with $\mathrm{S}$ and compost applications together. These findings may be cleared by relative changes $(\mathrm{RC})$ values (\%) of soil $\mathrm{pH}, \mathrm{EC}$ and $\mathrm{CaCO}_{3}$ affected by individual and combined applications of $\mathrm{S}$ and compost, where these values were negative with wide variations depending on the studied soil properties and the treatments of added soil amendment .

Other studies attributed the decrease effect of $\mathrm{S}$ and compost on soil $\mathrm{pH}, \mathrm{EC}$ and $\mathrm{CaCO}_{3}$ to their reactions and reactions products which characterized by acidic effect (EI-Maddah et al., 2012; Hashemimajd et al., 2012; Ahmed, 2013; Mutowal et al., 2013 and El-Gamal, 2015).

Also, data in Table (3) show an increase effect of compost applications individually on soil content (\%) of OM, where the individual applications of $S$ resulted in a decrease of this content. Combined applications of compost and $S$ resulted a little increase of soil content of OM compared with that found with the individual applications of compost. So, RC (\%) values of soil content of OM were positive in both individual applications of compost and combined treatments of compost and $S$, while these values were negative with the individual treatments of $S$. 
Abou Hussien, et al.,

The decrease effect of $S$ on soil content of OM may be resulted from oxidation reactions associated $S$ applications which resulted more oxidation of soil organic matter (Pandey and Shukla, 2006). In this respect, Aiad (2010) and Gohar (2011) obtained on similar results.

Data of CEC (meq/100 g) of calcareous sandy soil presented in Table (3) show that, increasing application rates of added $S$ and compost individually and together resulted in an increase of soil CEC. According to the found increases of soil CEC, the studied treatments takes the order combined applications of $S$ and compost $>$ individual applications of compost > individual applications of S. Mahmoud et al. (2001) and El-Gamal (2015) showed that applications of gypsum and sulphur alone or combination with different resources of organic matter improved soil properties and its fertility.i.e. $\mathrm{pH}, \mathrm{EC}, \mathrm{ESP}, \mathrm{CEC}$ and availability macro and micronutrients. In this respect, Wang et al. (2009); Aiad (2010); Gohar (2011) and El-Maddah et al. (2012) obtained on similar results.

Table (3): Effect of sulphur and compost additives on pH, EC, OM, CEC and $\mathrm{CaCO}_{3}$ in calcareous soil and its relative change "RC" (\%) as affected by sulphur additives.

\begin{tabular}{|c|c|c|c|c|c|c|c|c|c|c|c|}
\hline \multicolumn{2}{|c|}{$\begin{array}{l}\text { The studied } \\
\text { treatments }\end{array}$} & \multicolumn{2}{|c|}{$\begin{array}{c}\text { pH } \\
1: 2.5 \text { (compost } \\
: \text { water) susp. }\end{array}$} & \multicolumn{2}{|c|}{$\begin{array}{c}\text { EC } 1: 5\left(\mathrm{dSm}^{-1}\right) \\
\text { (compost : } \\
\text { water) extract }\end{array}$} & \multicolumn{2}{|c|}{ OM \% } & \multicolumn{2}{|c|}{$\begin{array}{c}\text { CEC } \\
\text { meq/100g }\end{array}$} & \multicolumn{2}{|c|}{$\mathrm{CaCO}_{3}(\%)$} \\
\hline $\begin{array}{c}\text { Compo } \\
\text { st }\end{array}$ & Sulphur & value & $\begin{array}{l}\mathrm{RC} \\
\%\end{array}$ & value & $\begin{array}{l}\mathrm{RC} \\
\%\end{array}$ & value & RC \% & value & $\begin{array}{l}\mathrm{RC} \\
\%\end{array}$ & value & $\mathrm{RC} \%$ \\
\hline \multirow{4}{*}{$\mathrm{CO}$} & so & 8.20 & 0 & 1.36 & 0 & 0.60 & 0 & 10.50 & 0 & 13.84 & 0 \\
\hline & S1 & 8.18 & -0.24 & 1.32 & -2.94 & 0.57 & -5 & 10.65 & 1.43 & 13.15 & -4.99 \\
\hline & S2 & 8.12 & -0.98 & 1.30 & -4.41 & 0.52 & -13.3 & 10.90 & 3.81 & 12.25 & -11.5 \\
\hline & S3 & 7.95 & -3.05 & 1.20 & $\mid-11.8$ & 0.50 & -16.7 & 11.10 & 5.71 & 11.65 & -15.8 \\
\hline \multicolumn{2}{|c|}{ Mean } & 8.61 & & 1.30 & & 0.55 & & 10.79 & & 12.72 & \\
\hline \multirow{4}{*}{ C1 } & so & 8.17 & 0 & 1.34 & 0 & 0.79 & 0 & 11.80 & 0 & 13.11 & 0 \\
\hline & S1 & 8.12 & -0.61 & 1.31 & -2.24 & 0.74 & -6.33 & 11.98 & 1.53 & 12.75 & -4.99 \\
\hline & S2 & 8.05 & $\mid-1.47$ & 1.25 & -6.72 & 0.71 & -10.1 & 12.23 & 3.64 & 11.95 & -11.5 \\
\hline & S3 & 7.88 & -3.55 & 1.13 & -15.7 & 0.69 & -12.7 & 12.80 & 8.47 & 11.05 & -15.8 \\
\hline \multicolumn{2}{|c|}{ Mean } & 8.06 & & 1.26 & & 0.73 & & 12.20 & & 12.22 & \\
\hline \multirow{4}{*}{ C2 } & so & 7.98 & 0 & 1.28 & 0 & 0.92 & 0 & 13.50 & 0 & 12.50 & 0 \\
\hline & S1 & 7.88 & $\mid-1.25$ & 1.26 & $\mid-1.56$ & 0.85 & -7.61 & 13.70 & 1.48 & 11.90 & -4.8 \\
\hline & S2 & 7.79 & -2.38 & 1.15 & $\mid-10.2$ & 0.78 & -15.2 & 13.98 & 3.56 & 11.10 & -11.2 \\
\hline & S3 & 7.68 & -3.76 & 0.95 & -25.8 & 0.75 & -18.5 & 14.15 & 4.81 & 10.78 & -13.8 \\
\hline \multicolumn{2}{|c|}{ Mean } & 7.83 & & 1.16 & & 0.83 & & 13.83 & & 11.57 & \\
\hline
\end{tabular}

C0, C1 and 2. 0, 1 and $2 \%$ compost and S0, S1, S2 and S3 = 0, 200, 300, $400 \mathrm{~kg} \mathrm{~S} /$ fed of sulphur respectively. 


\section{Available macronutrients}

The presented data in Table (4) show that, calcareous sandy soil contents $(\mathrm{mg} / \mathrm{kg})$ of available $\mathrm{N}, \mathrm{P}, \mathrm{K}, \mathrm{Ca}, \mathrm{Mg}$ and $\mathrm{S}$ increased with the increase rates of added compost and $S$ alone or in together. The found content of available macronutrients varied widely from nutrient to another, where the highest content was found with available $\mathrm{K}$ followed by available $\mathrm{N}$, while the lowest one was found with available $P$ followed by that found with the sandy soil content of available $\mathrm{S}$. The found wide variations in calcareous sandy soil content of available macronutrients depending on the initial contents of these nutrients in the soil and the used soil amendments and also on the effect of these amendments on soil properties. Except the soil content of available $S$, the increase of soil content available macronutrients resulted from the individual applications of compost were higher than these resulted from the individual applications of S. Combined applications of $\mathrm{S}$ and compost were associated by high content of the determined available macronutrients compared with those resulted from their individual applications.

So, all RC (\%) values of calcareous sandy soil content of available macronutrients affected by $S$ and compost applications compared with the control treatments were positive and increased with the increase rates of $S$ and compost alone or together. With all macronutrients, the highest RC (\%) values were found in the soil treated by $S$ and compost together, but the lowest values were found in the soil treated by $S$ alone (Table,). At the same treatment of the tested soil amendments, RC (\%) values varied from nutrient to another, where the highest value was recorded with $\mathrm{N}$ followed with $\mathrm{S}$ and the lowest one found with $\mathrm{Ca}$. Similar increase effect of $\mathrm{S}$ and compost or other organic matter resources were reported by Abdel Dayem et al. (2008); Aiad (2010); Gohar (2011); El-Maddah et al. (2012) and El-Gamal (2015).

Table (4): Effect of sulphur and compost additives on concentration $(\mathrm{mg} / \mathrm{kg})$ of $\mathrm{N}, \mathrm{P}, \mathrm{K}$, $\mathrm{Ca}, \mathrm{Mg}$ and $\mathrm{S}$ in calcareous soil and its relative change "RC" (\%) as affected by sulphur additives.

\begin{tabular}{|c|c|c|c|c|c|c|c|c|c|c|c|c|c|}
\hline \multirow{2}{*}{\multicolumn{2}{|c|}{\begin{tabular}{|c|c|}
$\begin{array}{c}\text { The studied } \\
\text { treatments }\end{array}$ \\
Compost & Sulphur \\
\end{tabular}}} & \multicolumn{2}{|c|}{$\mathbf{N}$} & \multicolumn{2}{|c|}{$\mathbf{P}$} & \multicolumn{2}{|c|}{$\mathbf{K}$} & \multicolumn{2}{|c|}{$\mathrm{Ca}$} & \multicolumn{2}{|c|}{ Mg } & \multicolumn{2}{|c|}{$\mathbf{S}$} \\
\hline & & $\mathrm{mg} / \mathrm{kg}$ & RC \% & $\mathrm{mg} / \mathrm{kg}$ & RC \% & $\mathrm{mg} / \mathrm{kg}$ & RC \% & $\mathrm{mg} / \mathrm{kg}$ & RC \% & $\mathrm{mg} / \mathrm{kg}$ & RC \% & $\mathrm{mg} / \mathrm{kg}$ & RC \% \\
\hline \multirow{4}{*}{$\mathrm{CO}$} & so & 44.10 & 0 & 4.15 & 0 & 908 & 0 & 20.10 & 0 & 10.30 & 0 & 7.50 & 0 \\
\hline & S1 & 46.50 & 5.44 & 4.70 & 13.25 & 928 & 2.20 & 20.88 & 3.88 & 10.48 & 1.75 & 7.95 & 6.00 \\
\hline & S2 & 49.80 & 12.93 & 4.92 & 18.55 & 963 & 6.06 & 21.62 & 7.56 & 10.81 & 4.95 & 8.75 & 16.67 \\
\hline & S3 & 54.65 & 23.92 & 5.05 & 21.69 & 995 & 9.58 & 22.10 & 9.95 & 11.25 & 9.22 & 9.50 & 26.67 \\
\hline \multicolumn{2}{|c|}{ Mean } & 48.76 & & 4.71 & & 948.5 & & 21.18 & & 10.71 & & 8.43 & \\
\hline \multirow{4}{*}{ C1 } & So & 48.50 & 0 & 4.41 & 0 & 932 & 0 & 21.50 & 0 & 10.55 & 0 & 7.65 & 0 \\
\hline & S1 & 55.30 & 14.02 & 4.95 & 12.24 & 950 & 1.93 & 21.95 & 2.09 & 10.75 & 1.90 & 8.15 & 6.54 \\
\hline & S2 & 60.80 & 25.36 & 5.23 & 18.59 & 985 & 5.69 & 22.70 & 5.58 & 11.25 & 6.64 & 8.92 & 16.60 \\
\hline & S3 & 65.12 & 34.27 & 5.44 & 23.36 & 1042 & 11.80 & 23.45 & 9.07 & 11.60 & 9.95 & 9.90 & 29.41 \\
\hline \multicolumn{2}{|c|}{ Mean } & 57.43 & & 5.01 & & 977.25 & & 22.4 & & 11.04 & & 8.66 & \\
\hline \multirow{4}{*}{$\mathrm{C} 2$} & so & 51.30 & 0 & 5.10 & 0 & 945 & 0 & 21.85 & 0 & 10.72 & 0 & 7.91 & 0 \\
\hline & S1 & 61.70 & 20.27 & 5.61 & 10.00 & 970 & 2.65 & 22.40 & 2.52 & 10.98 & 2.43 & 8.70 & 9.99 \\
\hline & S2 & 68.70 & 33.92 & 5.98 & 17.25 & 1010 & 6.88 & 23.15 & 5.95 & 11.63 & 8.49 & 9.45 & 19.47 \\
\hline & S3 & 72.50 & 41.33 & 6.18 & 21.18 & 1090 & 15.34 & 24.10 & 10.30 & 11.98 & 11.75 & 10.65 & 34.64 \\
\hline \multicolumn{2}{|c|}{ Mean } & 63.55 & & 5.72 & & 1003.8 & & 22.88 & & 11.33 & & 9.18 & \\
\hline
\end{tabular}

C0, C1 and C2. 0, 1 and $2 \%$ compost and S0, S1, S2 and S3= 0, 200, 300, $400 \mathrm{~kg} \mathrm{S/fed} \mathrm{of} \mathrm{sulphur}$ respectively. 


\section{Available Micronutrients}

The presented data in Table (5) show that, calcareous sandy soil content $(\mathrm{mg} / \mathrm{kg})$ of available micronutrients.i.e. $\mathrm{Fe}, \mathrm{Zn}, \mathrm{Mn}$ and $\mathrm{Cu}$ were increased with the increase added rates of $S$ and compost individually and in together. The found increases in the sandy soil content of available micronutrients resulted from the individual applications of $S$ were higher than that resulted from the individual treatments of compost. More increase of soil content of available micronutrients was resulted from combined applications of $S$ and compost especially at high their application rates. So, with all treatments of $S$ and compost, $R C$ (\%) values of the soil content of available micronutrients were positive (Table, 5). The highest values of $\mathrm{RC}$ were associated the combined treatment of $S$ and compost followed by those associated the individual applications of S. Generally, the tested sandy soil characterized by low content of available micronutrients. The highest content of available micronutrients was found with $\mathrm{Mn}$ followed $\mathrm{Fe}$ and the lowest one was found with $\mathrm{Cu}$. This trend was found with all treatments under study. The found increases in calcareous sandy soil content of available $\mathrm{Fe}, \mathrm{Zn}, \mathrm{Mn}$ and $\mathrm{Cu}$ due to $S$ and compost applications may be explained based on the transformations and reactions of the added amendments in the soil and their effect of the different soil properties (El-Gamal, 2015). In this respect, Abdel Hafez (2008); Ahmed (2013) and Chen et al. (2013), obtained on similar results.

Table (5): Effect of sulphur and compost additives on concentration $(\mathrm{mg} / \mathrm{kg})$ of micronutrients in calcareous soil and its relative change "RC" (\%) as affected by sulphur additives.

\begin{tabular}{|c|c|c|c|c|c|c|c|c|c|}
\hline \multicolumn{2}{|c|}{$\begin{array}{l}\text { The studied } \\
\text { treatments }\end{array}$} & \multicolumn{2}{|c|}{$\mathrm{Fe}$} & \multicolumn{2}{|c|}{$\mathrm{Zn}$} & \multicolumn{2}{|c|}{ Mn } & \multicolumn{2}{|c|}{$\mathrm{Cu}$} \\
\hline Compost & Sulphur & $\mathrm{mg} / \mathrm{kg}$ & RC \% & $\mathrm{mg} / \mathrm{kg}$ & RC \% & $\mathrm{mg} / \mathrm{kg}$ & RC \% & $\mathrm{mg} / \mathrm{kg}$ & RC \% \\
\hline \multirow{4}{*}{$\mathrm{CO}$} & so & 4.85 & 0 & 1.80 & 0 & 6.11 & 0 & 0.75 & 0 \\
\hline & S1 & 4.98 & 2.68 & 1.93 & 7.22 & 6.35 & 3.93 & 0.83 & 10.67 \\
\hline & S2 & 5.22 & 7.63 & 2.12 & 17.78 & 6.65 & 8.84 & 0.93 & 24.00 \\
\hline & S3 & 5.50 & 13.40 & 2.40 & 33.33 & 7.05 & 15.38 & 1.15 & 53.33 \\
\hline \multicolumn{2}{|c|}{ Mean } & 5.14 & & 2.06 & & 6.54 & & 0.92 & \\
\hline \multirow{4}{*}{ C1 } & so & 5.10 & 0 & 1.95 & 0 & 6.50 & 0 & 0.88 & 0 \\
\hline & S1 & 5.35 & 4.90 & 2.15 & 10.26 & 6.82 & 4.92 & 1.03 & 17.05 \\
\hline & S2 & 5.75 & 12.75 & 2.50 & 28.21 & 7.41 & 14.00 & 1.22 & 38.64 \\
\hline & S3 & 6.12 & 20.00 & 3.10 & 58.97 & 7.95 & 22.31 & 1.50 & 70.45 \\
\hline \multicolumn{2}{|c|}{ Mean } & 5.58 & & 2.43 & & 7.17 & & 1.16 & \\
\hline \multirow{4}{*}{$\mathrm{C2}$} & so & 5.40 & 0 & 2.11 & 0 & 6.88 & 0 & 0.98 & 0 \\
\hline & S1 & 5.82 & 7.78 & 2.40 & 13.74 & 7.30 & 6.10 & 1.12 & 14.29 \\
\hline & S2 & 6.30 & 16.67 & 2.95 & 39.81 & 7.90 & 14.83 & 1.40 & 42.86 \\
\hline & S3 & 6.78 & 25.56 & 3.63 & 72.04 & 8.62 & 25.29 & 1.78 & 81.63 \\
\hline \multicolumn{2}{|c|}{ Mean } & 6.08 & & 2.77 & & 7.68 & & 1.32 & \\
\hline
\end{tabular}

C0, C1 and C2. 0, 1 and $2 \%$ compost and S0, S1, S2 and S3= 0, 200, 300, $400 \mathrm{~kg} \mathrm{S/fed} \mathrm{of} \mathrm{sulphur}$ respectively. 


\section{Dry matter yield of barley plants}

The presented data in Table (6) show the dry matter yield ( $\mathrm{g} / \mathrm{pot}$ ) of barley plants affected by individual and combined treatments of $S$ and compost. Increasing rates of added $S$ and compost resulted in an increase of dry matter yield of barley plants (roots and shoots). With roots and shoots, the highest dry matter yields and its RC (\%) values were associated the combined applications of $S$ and compost and the lowest values were resulted from individual applications of $\mathrm{S}$. These increases of barley plants dry matter yields (roots and shoots) may be attributed to the enhancing effect of the tested soil amendments on plant growth as a result of improving soil properties and increased its content of available nutrients (Aiad, 2010 and El-Gamal, 2015). Abou Hussien (1999) and El-Sharawy (2008) found that, $S$ additions in different sources resulted in an increase of dry matter yield of corn plants. Improving growth media, rhizosphere area and soil chemical properties and also increasing the soil content of available nutrients resulted from compost applications were the main reasons for the found increases od dry matter yield of barley plants (Gohar, 2011 and Nada, 2011).

Table (6): Dry matter yield (g/pot) of barley plants (roots and shoots) and its relative changes "RC" (\%) affected by compost and sulphur applications and agronomical efficiency "AE" (g plant/g S or Compost) of compost and sulphur additions under calcareous soil conditions.

\begin{tabular}{|c|c|c|c|c|c|c|c|c|c|}
\hline \multirow{2}{*}{\multicolumn{2}{|c|}{$\begin{array}{l}\text { The studied } \\
\text { treatments }\end{array}$}} & \multicolumn{4}{|c|}{ Dry matter yield } & \multicolumn{4}{|c|}{ Agronomical Efficiency } \\
\hline & & \multicolumn{2}{|c|}{ Roots } & \multicolumn{2}{|c|}{ Shoots } & \multicolumn{2}{|c|}{ compost } & \multicolumn{2}{|c|}{ sulphur } \\
\hline compost & Sulphur & $\mathrm{mg} / \mathrm{pot}$ & $\mathrm{RC} \%$ & $\mathrm{mg} / \mathrm{pot}$ & $\mathrm{RC} \%$ & Roots & Shoots & Roots & Shoots \\
\hline \multirow{4}{*}{$\mathrm{CO}$} & so & $5.21^{j}$ & 0 & $16.60^{j}$ & 0 & - & - & - & - \\
\hline & S1 & $5.63^{\mathrm{ij}}$ & 8.06 & $17.26^{i}$ & 3.98 & - & - & 0.42 & 0.66 \\
\hline & S2 & $5.79^{f i}$ & 11.13 & $17.72^{\mathrm{fi}}$ & 6.75 & - & - & 0.39 & 0.75 \\
\hline & S3 & $5.94^{\mathrm{fi}}$ & 14.01 & $18.28^{\text {ef }}$ & 10.12 & - & - & 0.37 & 0.84 \\
\hline \multicolumn{2}{|c|}{ Mean } & $5.64^{\mathrm{c}}$ & - & $17.47^{\mathrm{c}}$ & - & - & - & 0.39 & 0.75 \\
\hline \multirow{4}{*}{ C1 } & so & $5.60^{\mathrm{ij}}$ & 0 & $17.70^{\mathrm{i}}$ & 0 & 0.008 & 0.022 & - & - \\
\hline & S1 & $6.00^{f i}$ & 7.14 & $18.13^{\text {ef }}$ & 2.43 & 0.007 & 0.017 & 0.40 & 0.43 \\
\hline & S2 & $6.70^{\mathrm{de}}$ & 19.64 & $19.22^{d}$ & 8.59 & 0.018 & 0.030 & 0.73 & 1.01 \\
\hline & S3 & $7.30^{b}$ & 30.36 & $20.98^{b}$ & 18.53 & 0.027 & 0.054 & 0.85 & 1.64 \\
\hline \multicolumn{2}{|c|}{ Mean } & $6.40^{\mathrm{b}}$ & - & $19.01^{b}$ & - & 0.015 & 0.031 & 0.66 & 1.03 \\
\hline \multirow{4}{*}{$\mathrm{C} 2$} & so & $5.96^{f i}$ & 0 & $18.46^{\mathrm{e}}$ & 0 & 0.008 & 0.019 & - & - \\
\hline & S1 & $6.35^{\mathrm{ef}}$ & 6.54 & $18.70^{\mathrm{de}}$ & 1.30 & 0.007 & 0.014 & 0.39 & 0.24 \\
\hline & S2 & $7.19^{\text {cd }}$ & 20.64 & $19.96^{c}$ & 8.13 & 0.014 & 0.022 & 0.82 & 1.00 \\
\hline & S3 & $8.11^{a}$ & 36.07 & $22.49^{a}$ & 21.83 & 0.022 & 0.042 & 1.08 & 2.02 \\
\hline \multicolumn{2}{|c|}{ Mean } & & $6.90^{a}$ & & $19.90^{\mathrm{a}}$ & 0.013 & 0.024 & 0.76 & 1.09 \\
\hline
\end{tabular}

C0, C1 and C2.0, 1 and $2 \%$ compost and S0, S1, S2 and S3= 0, 200, 300, $400 \mathrm{~kg}$ S/fed of sulphur respectively. 


\section{Agronomical efficiency of sulphur fertilizer and compost additives}

The presented data in Table (6) show agronomic efficiency (AE) of both $S$ and compost as (g plant/g soil amendment) of the obtained dry matter yield of roots and shoots of barley plants grown in calcareous soil. These data show that, $A E$ values of both dry weights of barley plants were varied widely depending on added rates of $S$ and compost. The highest values of $\mathrm{AE}$ were associated the high application rates of $S$ and compost and decreased with the decrease of application rates. These findings mean that, the higher applications of $S$ and compost have a high efficiency on dry matter yield of barley plants (roots and shoots) compared with these of low application rates. The same treatments of $S$ and compost, $\mathrm{AE}$ values of shoots were higher than that of roots. This trend resulted from high dry matter yields of shoots than these of roots in the same plant. In addition, for dry weights of barley plants (roots and shoots) treated by $S$ and compost together appeared high values of $A E$ for both compost and $S$ compared with those found with the individual treatments of $S$ and compost. These findings mean that, efficiency of different applications of $S$ increased in the soil treated by compost. These results are in agreement with those obtained by Nada (2011)

\section{Plant content of macronutrients}

The presented data in Table (7) show shoots of barley plants uptake $(\mathrm{mg} / \mathrm{kg})$ of the determined macronutrients $(\mathrm{N}, \mathrm{P}, \mathrm{K}, \mathrm{Ca}, \mathrm{Mg}$ and $S$ ) affected by different applications of compost and $S$ under calcareous soil conditions. With all treatments of compost and $S$ individually and in together, uptake of macronutrients increased clearly with the increase rates of added compost and $\mathrm{S}$, where the highest uptake was found in the plants treated by compost and $S$ together followed by that found in the plants treated by compost alone. So, RC (\%) values of the determined macronutrients uptake were positive with all compost and $S$ treatments, where these values become more positive at high application rates especially in the combined treatments. These findings are in agreement with the effect of the tested soil amendments on improving soil properties and increasing the soil content of available macronutrients (Nada, 2011 and El-Gamal, 2015). According to the found uptake values, the determined macronutrients takes the order $\mathrm{N}>\mathrm{Ca}>\mathrm{P}>\mathrm{S}>\mathrm{K}>\mathrm{Mg}$. this order depending on the tested soil content of available macronutrients and its relation with the added soil amendments and also may be related with the plant ability of these nutrients uptake. These results are in agreement with these obtained by Aiad (2010); Belal (2011); Gohar (2011); Nada (2011) and El-Gamal (2015).

\section{Plant content of micronutrients}

The data in Table (8) show that increasing application rates of compost and $S$ alone and together were associated by clear increase of the determined micronutrient ( $\mathrm{Fe}, \mathrm{Zn}, \mathrm{Mn}$ and $\mathrm{Cu}$ ) uptake (mg/pot) by barley plants grown in calcareous sandy soil. So, the highest uptake of these micronutrients were found in the plants treated by compost and $S$ together followed by that found in the plants treated by compost alone. With all treatments of compost and S, RC (\%) values of micronutrients uptake by barley plants were positive and increased with the increase rates of added compost and $S$ especially in their combined treatments. Absolute values of the determined micronutrients by barley plants varied from nutrient to another, where the highest uptake was found with Fe followed by $\mathrm{Mn}$, but the lowest one was found with $\mathrm{Cu}$. The found increases of the determined micronutrients uptake by barley plants as a result of compost and $S$ application attributed to the improve of soil properties and increase of soil content of available micronutrients. These results are in agreement with these obtained by Belal (2011); Gohar (2011) and El-Gamal (2015). 
Table (7): Macronutrients uptake (mg/pot) by barley plants and its relative changes "RC" (\%) affected by different application rates of compost and sulphur under calcareous sandy soil conditions.

\begin{tabular}{|c|c|c|c|c|c|c|c|c|c|c|c|c|c|}
\hline \multicolumn{2}{|c|}{$\begin{array}{c}\text { The studied } \\
\text { treatments }\end{array}$} & \multicolumn{2}{|l|}{$\mathbf{N}$} & \multicolumn{2}{|c|}{$\mathbf{P}$} & \multicolumn{2}{|c|}{$\mathbf{k}$} & \multicolumn{2}{|c|}{$\mathrm{Ca}$} & \multicolumn{2}{|c|}{ Mg } & \multicolumn{2}{|c|}{$\mathbf{S}$} \\
\hline compost & sulphu & $\mathrm{mg} / \mathrm{pot}$ & RC \% & $\mathrm{mg} / \mathrm{pot}$ & RC \% & $\mathrm{mg} /$ pot & RC \% & $\mathrm{mg} / \mathrm{pot}$ & RC \% & $\mathrm{mg} / \mathrm{pot}$ & RC \% & $\mathrm{mg} / \mathrm{pot}$ & RC \% \\
\hline \multirow{4}{*}{$\mathrm{CO}$} & So & 194.22 & 0 & 78.02 & 0 & 84.66 & 0 & 87.98 & 0 & 49.80 & 0 & 64.74 & 0 \\
\hline & S1 & 231.28 & 19.08 & 89.75 & 15.03 & 93.20 & 10.09 & 110.46 & 25.55 & 58.68 & 17.83 & 89.75 & 38.63 \\
\hline & $\mathrm{S2}$ & 248.08 & 27.73 & 104.55 & 34.00 & 97.46 & 15.12 & 122.27 & 38.97 & 72.65 & 45.88 & 116.95 & 80.65 \\
\hline & S3 & 263.23 & 35.53 & 115.16 & 47.60 & 107.85 & 27.39 & 138.93 & 57.91 & 87.74 & 76.18 & 127.96 & 97.65 \\
\hline \multicolumn{2}{|c|}{ Mean } & 234.20 & & 96.87 & & 95.79 & & 114.91 & & 67.22 & & 99.85 & \\
\hline \multirow{4}{*}{ C1 } & so & 217.71 & 0 & 100.89 & 0 & 93.81 & 0 & 113.28 & 0 & 60.18 & 0 & 76.11 & 0 \\
\hline & S1 & 261.07 & 19.92 & 106.97 & 6.03 & 99.72 & 6.30 & 125.10 & 10.43 & 72.52 & 20.51 & 105.15 & 38.16 \\
\hline & S2 & 288.30 & 32.42 & 115.32 & 14.30 & 111.48 & 18.84 & 142.23 & 25.56 & 96.10 & 59.69 & 134.54 & 76.77 \\
\hline & S3 & 323.09 & 48.40 & 142.66 & 41.40 & 136.37 & 45.37 & 167.84 & 48.16 & 111.19 & 84.76 & 161.55 & 112.26 \\
\hline \multicolumn{2}{|c|}{ Mean } & 272.54 & & 116.46 & & 110.34 & & 137.11 & & 85.00 & & 119.34 & \\
\hline \multirow{4}{*}{$\mathrm{C2}$} & so & 239.98 & 0 & 123.68 & 0 & 101.53 & 0 & 129.22 & 0 & 73.84 & 0 & 79.38 & 0 \\
\hline & S1 & 274.89 & 14.55 & 132.77 & 7.35 & 110.33 & 8.67 & 140.25 & 8.54 & 86.02 & 16.50 & 123.42 & 55.48 \\
\hline & S2 & 329.34 & 37.24 & 145.71 & 17.81 & 129.74 & 27.78 & 159.68 & 23.57 & 109.78 & 48.67 & 149.70 & 88.59 \\
\hline & S3 & 386.83 & 61.19 & 179.92 & 45.47 & 155.18 & 52.84 & 193.41 & 49.67 & 137.19 & 85.79 & 188.92 & 137.99 \\
\hline \multicolumn{2}{|c|}{ Mean } & 307.76 & & 145.52 & & 122.51 & & 155.64 & & 101.71 & & 135.35 & \\
\hline
\end{tabular}

C0, C1 and C2. 0, 1 and $2 \%$ compost and S0, S1, S2 and S3= 0, 200, 300, $400 \mathrm{~kg}$ S/fed of sulphur respectively

Table (8): Micronutrients uptake (mg/pot) by barley plants and its relative changes "RC" (\%) affected by different application rates of compost and sulphur under calcareous sandy soil conditions.

\begin{tabular}{|c|c|c|c|c|c|c|c|c|c|}
\hline \multicolumn{2}{|c|}{$\begin{array}{l}\text { The studied } \\
\text { treatments }\end{array}$} & \multicolumn{2}{|c|}{$\mathrm{Fe}$} & \multicolumn{2}{|c|}{$\mathrm{Zn}$} & \multicolumn{2}{|c|}{ Mn } & \multicolumn{2}{|c|}{$\mathrm{Cu}$} \\
\hline Compost & Sulphur & $\mathrm{mg} /$ pot & RC \% & $\mathrm{mg} / \mathrm{pot}$ & RC \% & $\mathrm{mg} /$ pot & RC \% & $\mathrm{mg} / \mathrm{pot}$ & RC \% \\
\hline \multirow{4}{*}{ CO } & So & 28.47 & 0 & 2.41 & 0 & 22 & 0 & 0.57 & 0 \\
\hline & S1 & 30.46 & 6.99 & 3.76 & 56.02 & 24.13 & 9.68 & 0.83 & 45.61 \\
\hline & S2 & 37.00 & 29.96 & 4.25 & 76.35 & 25.22 & 14.64 & 1.07 & 87.72 \\
\hline & S3 & 41.73 & 46.58 & 4.75 & 97.10 & 26.65 & 21.14 & 1.20 & 110.53 \\
\hline \multicolumn{2}{|c|}{ Mean } & 34 & - & 4 & - & 25 & - & 1 & - \\
\hline \multirow{4}{*}{ C1 } & So & 36.99 & 0 & 3.81 & 0 & 24.16 & 0 & 0.73 & 0 \\
\hline & S1 & 38.34 & 3.65 & 4.04 & 6.04 & 25.89 & 7.16 & 0.97 & 32.88 \\
\hline & S2 & 45.46 & 22.90 & 4.71 & 23.62 & 28.12 & 16.39 & 1.33 & 82.19 \\
\hline & S3 & 51.15 & 38.28 & 5.77 & 51.44 & 33.84 & 40.07 & 1.63 & 123.29 \\
\hline \multicolumn{2}{|c|}{ Mean } & 43 & - & 5 & - & 28 & - & 1 & - \\
\hline \multirow{4}{*}{ C2 } & so & 40.15 & 0 & 4.06 & 0 & 27.65 & 0 & 0.90 & 0 \\
\hline & S1 & 42.54 & 5.95 & 4.64 & 14.29 & 28.20 & 1.99 & 1.07 & 18.89 \\
\hline & S2 & 48.90 & 21.79 & 5.35 & 31.77 & 35.43 & 28.14 & 1.51 & 67.78 \\
\hline & S3 & 57.46 & 43.11 & 6.70 & 65.02 & 40.82 & 47.63 & 1.92 & 113.33 \\
\hline \multicolumn{2}{|c|}{ Mean } & 47 & - & 5 & -- & 33 & - & 1 & - \\
\hline
\end{tabular}

C0, C1 and C2. 0, 1 and $2 \%$ compost and S0, S1, S2 and S3= 0, 200, 300, $400 \mathrm{~kg} \mathrm{S/fed} \mathrm{of} \mathrm{sulphur}$ respectively. 


\section{CONCLUSION}

The data of this study may be concluded that, to improve calcareous sandy soil properties and its content of available macro- and micronutrients and also its productivity may be occurred by some soil amendments such as compost and sulphur. Also, the agronomical efficiency of $S$ fertilization in calcareous sandy soil may be increased with compost applications.

\section{REFERANCES}

Abdel-Hafez, B. A. G. (2008). Studying the effect of sulphur application and potassium fertilizer under different irrigation regimes on some soil properties and yield of wheat and maize in middle delta soil. Ph. D. Thesis, Fac. Agric., Tanta Univ., Egypt.

Abdel-Dayem, A. O. A., A. Rashed, M. A. Fayid and M. S. Mahrous (2008). The effect of sulfur and gypsum treatments on some physical, chemical properties and availability of some nutrients in saline sodic soil. Egypt J. Applied, Sci. 23: 304317.

Abou Hussien, E. A. (1999). Soybean and corn response to different sulphur sources. J. Agric. Sci., Mansoura Univ. 24 (11): 7007-7021.

Ahmed, S. H. A. (2013). Chemical remediation of some degraded soil. $\mathrm{Ph}$. D. Thesis, Fac. of Agric., Ain Shams Univ., Egypt.

Aiad, N. A. (2010). Application of organic wastes for sustainable of agriculture. Ph. D. Thesis, Fac. of Agric., Menoufia Univ., Egypt.

Barrington, S., D. Choinière, M. Trigui and W. Knight (2002). Effect of carbon source on compost nitrogen and carbon losses. Bioresource Technology. 83: 189-194.

Barrow, N. J. (1961). Studies on mineralization of sulfur from soil organic matter. Australian Journal of Agricultural Research. 12: 306- 319.

Belal, E. E. E. (2011). Kineties of humic substances in calcareous soils under organic farming system. Ph. D. Thesis, Fac. of Agric., El-Fayoum Univ., Egypt.

Chapman, H. D. and P. F. Partt (1961). Methods of Analysis for Soils, Plants and Water Agric. Publ. University of California, Riverside.

Chen, M., X. Cui, F. Bai and J. Wang (2013). Effect of two biogas residues application on copper and zinc fractionation and release in different soils. Journal of Environmental Sciences, 25 (9): 1865-1873.

Cottenie, A., M. Verloo, L. Kickens, G. Velghe and R. Camerlynck (1982). Chemical analysis of plants and soils. Laboratory of Analytical and Agrochemistry. State University, Ghent Belgium, pp: 63.

Edwards, Pamela J. (1998). Sulfur Cycling, Retention, and Mobility in Soils: A Review. USDA forest service 5 Radnor Corp CTR suite 200. Radnor PA 190874585.

El-Gamal, B. A. H. (2015). Effect of some soil amendments on soil conditions and plant growth. Ph. D. Thesis, Fac. of Agric., Menoufia Univ., Egypt.

El-Maddah, E. I., M. E. D. El-Sodany and A. A. Mahmoud (2012). Effect of different tillage systems and soil conditioners on some chemical properties and status of nutrients. Egypt of Appl. Sci., 27 (12): 968- 995.

El-Sharawy, M. A. O. (2008). Improvement of some chemical properties productivity of some salt- affected calcareous soil. Egypt Journal Soil Sci., 48 (2): 159-168.

Gohar, H. M. (2011). Effect of some plant residues on soil properties and plant growth in newly reclaimed soils. M. Sc. Thesis, Fac. of Agric., Menoufia Univ., Egypt.

Hashemimajd, K., T. M. Farani and S. J. Somarin (2012). Effect of elemental sulphur and compost on electrical conductivity and phosphorus availability of one clay soil. African Journal of Biotechnology. 11 (6): 1425-1432. 
Imas, P. (2000). Integrated nutrient management for sustaining crop yield in calcareous soils. PP: 1-21. In GAU- PRIIIPI National symposium on: Balanced nutrition of groundnut and other field crops grown in calcareous soil of India, International (Potash institute).

Klute, A. and C. Dirksen (1986). Hydraulic conductivity and diffusivity. In Klute, A. (Ed.) Methods of soil analysis. Part (I) Physical and mineralogical methods, $2^{\text {nd }}$ ed. Agron, Monogr. 9. ASA-SSA, Madison, WI, PP. 687- 734.

Mahmoud, M. R., N. M. Badr and M. H. E. Salem (2001). Influence of gypsum, sulphur and farmyard manure application on some properties and yield of sunflower grown on saline- sodic soil. Menoufia, J. Agric., Res., 26 (1): 215223.

Mathot, M. L. and R. L. Thélier-Huché (2009). Sulfur and nitrogen content as sulfur deficiency indicator for grasses. Euro. J. Agron., 30: 172- 176.

Mutowal, W., S. G. Al-Solaimani and S. M. Ismail (2013). Effect of sulphur amendments levels on calcareous saline sodic soil and squash yield in saudi Arabia. Asian J. of Science and Technology, 4 (12): 48-51.

Nada, W. M. A. (2011). Wood compost process engineering, properties and its impact on extreme soil characteristics. Ph.D. Thesis, Faculty of Mathematics and Natural Sciences, Potsdam University, Germany.

Nassar, K. E. M., M. M. El-Shouny and E. M. K. Behiry (2004). Improving the quantity and quality of wheat in salt affected soil. Zagzazig J. Agric., Res. 31 (6): 28612883.

Page, A. L., R. H. Miller and D. R. Keeney (1982). Methods of Soil Analysis, Part 2. Chemical and Microbiological properties second Edition. Wisconsin, U.S.A.

Pandey, C. and S. Shukla (2006). Effects of composted yard waste on water movement in sandy soil. Compost Science and Utilization, 14 (4): 252-259.

Qadir, M., A. Tubeileh, J. Akhtar, A. Larbi, P. S. Minhas and M. A. Khan (2008). Productivity enhancement of salt affected environments through crop diversification. Land Degradation and Development 19: 429- 453.

Snedecor, G. W. and G. W. Cochran (1980). Statistical Methods 6th Ed. lowa State Univ. Press; Ames, lowa; USA.

Stotzky, G. and A. G. Norman (1961). Factors limiting microbial activities in soil. II. The effect of sulfur. Archives of Microbiology, 40: 370- 382.

Wang, V. N. L., R. C. Dalal and R. S. B. Greene (2009). Carbon dynamics of sodic and saline soils following gypsum and organic material additions. A laboratory incubation. Appl. Soil Ecol., 41: $29-40$. 
تقييم كفاعة التسميد بالكبريت فى الأراض الجيرية المعاملة بالكمبوست

الحسينى عبدالغفار أبوحسين ، وائل محمد عبد الرحمن ندا ، محمد خالد السيد الجزيرى

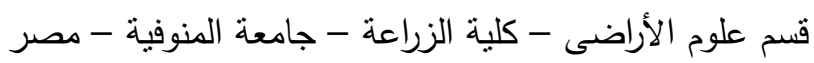

الملخص العربى

أجريت تجربة أصص بصوبة قسم علوم الأراضى - كلية الزراعة - جامعة المنوفية - مصر وذلك لدراسة تأثنير

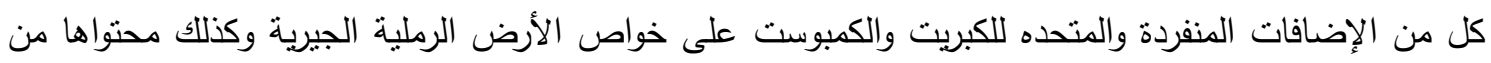

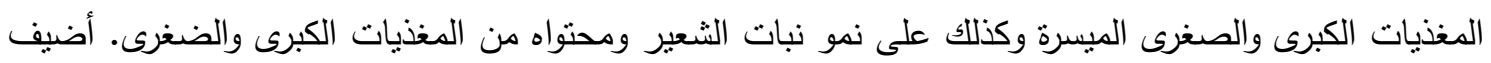
الكمبوست عند معدلات إضافة صفر و 1 و 2 \% بينما أضيف الكبريت على صورة كبريت عنصرى عند معدلات إضافة صفر و 100 و 200 و 400 ملليجرام / كجم. تم قياس الوزن الجاف لنبات الثعبر عند عمر 70 يوم كما قدر محتواه من المغذيات الكبرى والصغرى وكذلك تم تقدير بعض الخواص الكيميائية للأرض المستعملة بعد في الحصاد كما تم تقدير محتوى الأرض من المغذيات الكبرى والصغرى الميسرة. زيادة معدل الإضافة لكل من الكمبوست والكبريت فى صورة منفردة أو معاً كان مصحوباً بنقص فى قئ قيم رقم

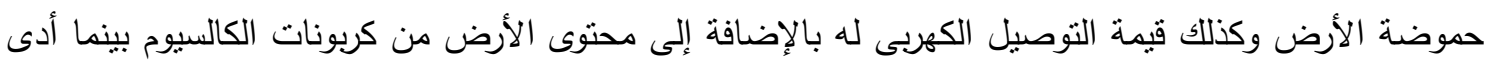

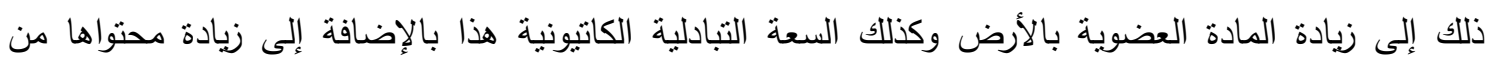

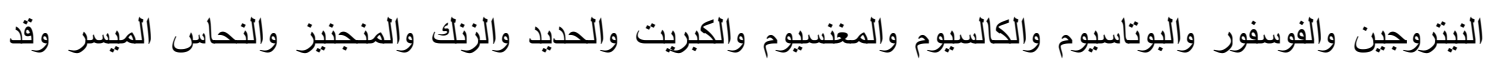

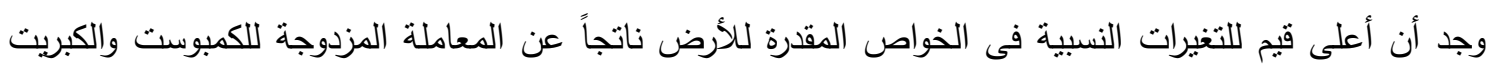
خاصة عند معدلات الإضافة المرتقعة. كما صاحب زيادة معدلات إضافة الكمبوست والكبريت منفرداً أو معاً زيادة فى محصول المادة الجافة لنبات الثعبر وكذلك محتواه من النيتروجين والفوسفور والبوتاسيوم والكالسيوم والمغنسيوم

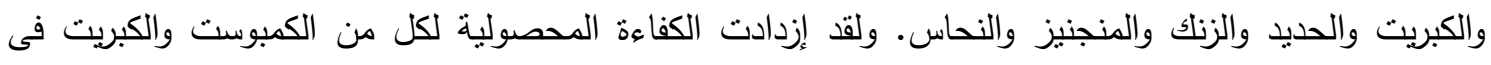
معاملات الإضافة المتحده ولهذا نوصى النتائج المتحصل عليها أنه لتحسين خواص الأراضى الرملية الجيرية وكذلك لزيادة خصوبتها وإنتاجيتها فإنه من الضرورى إضافة كل من الكمبوست والكبريت معاً فى إضافات مشتركة. 